\title{
Monitoring of heavy metals in selected Water Supply Systems in Poland, in relation to current regulations
}

\author{
Agnieszka Szuster-Janiaczyk ${ }^{* 1}$, Piotr Zeuschner ${ }^{1}$, Pawet Noga $^{2}$, Marta Skrzypczak ${ }^{2}$ \\ ${ }^{1}$ Faculty of Civil and Environmental Engineering, Poznan University of Technology, Berdychowo 4, \\ 60-965 Poznań, Poland \\ ${ }^{2}$ Graduate of the Poznan University of Technology
}

\begin{abstract}
The study presents an analysis of water quality monitoring in terms of the content of heavy metals, which is conducted in three independent water supply systems in Poland. The analysis showed that the monitoring of heavy metals isn't reliable - both the quantity of tested water samples and the location of the monitoring points are the problem. The analysis of changes in water quality from raw water to tap water was possible only for one of the analysed systems and indicate a gradual deterioration of water quality, although still within acceptable limits of legal regulations.
\end{abstract}

Keywords: heavy metal, lead, copper, tap water, water quality monitoring

\section{Introduction}

The water crisis in Flint, Michigan [1], and the effects of it, has shown how important for tap water quality is stability of water, corrosion control and monitoring of heavy metals in Water Supply Systems (WSS). According to World Health Organization guidelines [2,3], monitoring of heavy metals in drinking water has become one of the elements that have to be taken into account in estimating the risk to human health, and lead, in the International Program on Chemical Safety, is one of 10 chemicals important for public health [4]. This is related to the health risks that these contaminants carry. These metals can cause cancer, promote nervous system disorders and digestive and many others [5-9].

The presence of increased concentrations of heavy metals in WDS is due to the existence of their sources in this system such as transmission pipelines, internal systems, fittings and others. Release of this metals is associated with hydraulic conditions in system (age of water, velocity) and physical, chemical and biological parameters of water influenced on stability and corrosivity of water.

To determine the presence and level of these metals in sections of Water Supply System, the proper location of the monitoring points and the determination of the quantity and frequency of sampling are needed. Research and analysis conducted in the world still didn't give a precise answer on question - how the overall monitoring of water quality

* Corresponding author: agnieszka.szuster-janiaczyk@put.poznan.pl 
parameters should be. [10-13]. In the case of heavy metals monitoring, it's very important to take into account the accumulation of them in human organisms. That is why monitoring of heavy metals should be carried out in accordance with other principles which take into account the process of metal accumulation in consumer organisms [14-22]. The approach to this problem in Poland is fundamentally different from the proper approach, which may give a true picture of water quality in the network. In Polish regulation, as in the Directive [23], heavy metals are in audit monitoring, performed at a lower frequency than check monitoring, dependent on daily water production. That's way, in small systems, water quality assessment is often conducted in based on 1 water sample per year [24]. Water supply companies and sanitary inspection focus only on aspects shown if water quality meets the guidelines outlined in the Regulation of the Polish Minister of Health, the frequency and optimal localization of monitoring points aren't important for them. $[15,19,21,22]$.

In the United States, the EPA recommends an individual approach to monitoring of heavy metals for which separate recommendations have been made. They contain precise guidelines on the amount of sampling, place of collection and corrective action $[25,15,26$, 27]. In Japan, water quality monitoring is built individually for each WSS, but must be approved by the relevant supervisory authority. That gives the opportunity to monitor the dangers contaminants which might appear in WSS [28]. In Russia, monitoring plans are elaborate in two stages, what gives the opportunity to indicating water quality parameters which should be covered by precise monitoring [29]. One of the important suggestions in the guidelines is the location of the monitoring points, where a significant part of all tested samples have to be collected in the water network.

An important element of heavy metal monitoring, which determines the reliability of the results obtained, is the quantity of water samples taken. There are several methods to design it $[18,19,30]$. In Polish regulations, the quantity of taken water samples is dependent on average of daily water production and whether a concrete water quality parameter has been qualified for check or audit monitoring. In the USA and Russia, the number of samples taken depends on the number of consumers being supplied. It is also possible to designate the necessary quantity of analysed water samples based on statistical tests. Power analysis [31], allows to determine the minimum statistically required number of samples, on the basis of which we can obtain a true picture of the analysed factor.

A reliable view of water quality can be obtained through the correct location of water quality monitoring points. There are many methods to determine a localization of sampling point. These methods are characterized by varying degrees of complexity, for example from simple random data sampling to genetic algorithms [11,32]. They differ among themselves, among other things, the starting data needed to build them. These data can be eg. hydraulic model, water requirement, detection time, etc. Studies show that different methods give different results for localization of monitoring points in one system [11], but in every method the recommendation is that the decisive part of the monitoring point should be placed at the point of consumption of water to show real tap water quality. In Poland there is no good methodology for determining localization of sampling points for water quality assessment. The Regulation recommends the steady arrangement of monitoring points in the system, among other things, in consumers installation. Unfortunately, it's not specified, however, what part of the samples should be collected in network and what part in consumer installations. This leads to a situation in which a large proportion of the water samples analysed for heavy metal concentration comes from points located just behind the water treatment station. 


\subsection{Research objectives}

The article presents the assessment of heavy metals monitoring conducted in Poland, on the example of three similar Water Supply Systems (WSS1, WSS2, WSS3), in relation to current legal regulations and world trends. The first two systems (WSS1 and WSS2) are stand-alone technical objects, while WSS3 is part of a larger water supply system. The characteristics of these systems are presented in Table 1.

Table 1. The characteristics of analysed Water Supply Systems.

\begin{tabular}{|c|c|c|c|}
\hline- & WSS1 & WSS2 & WSS3 \\
\hline Number of recipients & 24.150 & 30.201 & 30.493 \\
\hline Type of water intake & 4 intakes - 13 deep wells & $\begin{array}{c}4 \text { intakes - } 9 \text { deep } \\
\text { wells }\end{array}$ & $\begin{array}{l}2 \text { intakes - ground and } \\
\text { infiltration water }\end{array}$ \\
\hline $\begin{array}{l}\text { Number of water } \\
\text { treatment plants }\end{array}$ & 3 & 3 & 1 \\
\hline Network structure & Looped-branched & Looped-branched & Looped-branched \\
\hline Network length & $350 \mathrm{~km}$ & $284 \mathrm{~km}$ & $183 \mathrm{~km}$ \\
\hline Materials & $\begin{array}{c}\text { ok. } 75 \% \text { PVC; } \\
18 \% \text { PE; } 7 \% \text { cast iron; } \\
0,15 \% \text { ductile iron }\end{array}$ & $\begin{array}{l}72 \% \text { PVC; } \\
23 \% \text { cast iron; } \\
5 \% \text { asbestos }\end{array}$ & - \\
\hline Water demand & $3533 \mathrm{~m}^{3} / \mathrm{d}$ & $3867 \mathrm{~m}^{3} / \mathrm{d}$ & $\left.4000 \mathrm{~m}^{3} / \mathrm{d}^{*}\right)$ \\
\hline Velocity & $\begin{array}{c}\text { About } 90 \% \text { below } \\
0.3 \mathrm{~m} / \mathrm{s}\end{array}$ & $\begin{array}{c}\text { About } 70 \% \text { below } \\
0,5 \mathrm{~m} / \mathrm{s}\end{array}$ & - \\
\hline
\end{tabular}

\subsection{Methodology}

The results of monitoring of heavy metals for each water supply systems, from different periods were analysed in this paper: for WSS1 - years $1970 \div 2016$; for WSS2 - years 2013 $\div 2016$; for WSS3 years $2012 \div 2014$. The results were divided for three subdivisions of WSS: raw water samples, post-treatment samples, and samples collected in the network. In case of WSS1 there was the ability to isolated samples from internal installations - tap water quality. The total number of analysed samples of water in general monitoring and audit monitoring is presented in Table 2. Table 2 shows also the number of parameters tested as part of water quality analyses.

Table 2. Number of samples for the whole study period (general/in audit monitoring)

\begin{tabular}{|c|c|c|c|}
\hline- & WSS1 & WSS2 & WSS3 \\
\hline raw water & 17 & 66 & 551 \\
\hline treated water & $33 / 2$ & $212 / 32$ & $1748 / 63$ \\
\hline in network & $28 / 8$ & $1298 / 32$ & $389 / 0$ \\
\hline Number of analysed parameters & 94 & 41 & 85 \\
\hline $\begin{array}{c}\text { Number of samples } \\
\text { with heavy metals analyzed - R/T/N*) }\end{array}$ & $3 / 15 / 8$ & $0 / 0 / 0$ & $504 / 63 / 0$ \\
\hline$*$ ()/ T/N- for raw water/for treated water/in network & \\
\hline
\end{tabular}

Samples in systems were retrieved with high variability over time. There are some years where only single results are available. Due to the lack of full data from all the water supply systems, there was no ability to produce a complete statistical analysis of the results obtained. For available results, average, minimum and maximum concentrations of the contaminant were determined. In this article the compliance of the performed monitoring with the Polish regulations on contaminants concentrations, the number of collected 
samples and the location of monitoring points has been analyzed. The results obtained were compared with world regulations. STATISTICA and Excel were used to develop the results.

\section{Results}

Table 3 summarizes the quantity of water samples taken as part of the water quality monitoring carried out. Data refers to the total number of samples and audit monitoring per year.

Table 3. Number of samples per one year (general/in audit monitoring)

\begin{tabular}{|c|c|c|c|}
\hline- & WSS1 & WSS2 & WSS3 \\
\hline raw water & 1 & 16.5 & 184 \\
\hline treated water & $4 / 0.25$ & $53 / 8$ & $583 / 21$ \\
\hline in network & $6 / 1$ & $324 / 8$ & $130 / 0$ \\
\hline Number of analysed parameters & 94 & 41 & 85 \\
\hline $\begin{array}{c}\text { Number of samples with } \\
\text { heavy metals analyzed - R/T/N*) }\end{array}$ & $0 / 0.25 / 1$ & $0 / 0 / 0$ & $168 / 21 / 0$ \\
\hline$*) \mathrm{R} / \mathrm{T} / \mathrm{N}$ - for raw water/for treated water/in network \\
\hline
\end{tabular}

The full analysis of heavy metal concentrations in the water distribution system was only possible for WSS1 (Table 4) because for WSS2 no heavy metals monitoring was carried out in the analyzed period, and in WSS3 all water quality monitoring points were located out of analysed system.

Table 4. Water quality in WSS1

\begin{tabular}{|c|c|c|c|c|c|}
\hline \multirow{2}{*}{ Parameter } & \multirow{2}{*}{ MP*) } & Raw water & Treated water & From network & From taps \\
\hline & & \multicolumn{4}{|c|}{$\operatorname{mean} / \min \div \max$} \\
\hline $\begin{array}{l}\text { Lead } \\
\mu \mathrm{g} / \mathrm{L}\end{array}$ & 10 & $\begin{array}{c}2 / \\
1 \div 4\end{array}$ & $\begin{array}{c}1.99 / \\
1 \div 5\end{array}$ & $\begin{array}{c}2.06 / \\
1.00 \div 4.00 \\
\end{array}$ & $\begin{array}{c}<1 / \\
<1 \div<1\end{array}$ \\
\hline $\begin{array}{l}\text { Copper } \\
\mathrm{mg} / \mathrm{L}\end{array}$ & 2 & $\begin{array}{c}0.05 / \\
0.001 \div 0.002 \\
\end{array}$ & $\begin{array}{c}<0.0015 / \\
<0.001 \div<0.002\end{array}$ & $\begin{array}{c}0.003 / \\
0.0013 \div 0.005\end{array}$ & $\begin{array}{c}<0.01 / \\
<0.01 \div<0.01\end{array}$ \\
\hline $\begin{array}{l}\text { Zinc } \\
\mathrm{mg} / \mathrm{L}\end{array}$ & & $\begin{array}{c}0.048 / \\
0.046 \div 0.05\end{array}$ & 0.05 & bd & $\mathrm{Bd}$ \\
\hline $\begin{array}{c}\text { Chrome } \\
\mu \mathrm{g} / \mathrm{L}\end{array}$ & 50 & $\begin{array}{c}2 / \\
1 \div 4 \\
\end{array}$ & $\begin{array}{l}2.9 / \\
1 \div 4\end{array}$ & $\begin{array}{c}1.6 / \\
1.0 \div 4.0\end{array}$ & $\begin{array}{c}2.7 / \\
1.9 \div 3.1\end{array}$ \\
\hline $\begin{array}{c}\text { Cadmium } \\
\mu \mathrm{g} / \mathrm{L}\end{array}$ & 5 & $\begin{array}{c}1.4 / \\
0.1 \div 1\end{array}$ & $\begin{array}{c}0.22 / \\
0.1 \div 0.5\end{array}$ & $\begin{array}{c}0.14 / \\
0.1 \div 0.3 \\
\end{array}$ & $\begin{array}{c}0.1 / \\
0.1 \div 0.1\end{array}$ \\
\hline $\begin{array}{c}\text { Mercury } \\
\mu \mathrm{g} / \mathrm{L}\end{array}$ & 1 & $\begin{array}{c}0.08 / \\
0.05 \div 0.1 \\
\end{array}$ & $\begin{array}{c}0.06 / \\
0.01 \div 0.1 \\
\end{array}$ & $\begin{array}{c}0.076 / \\
0.03 \div 0.1\end{array}$ & $\begin{array}{c}0.2 / \\
0.2 \div 0.2 \\
\end{array}$ \\
\hline
\end{tabular}

\section{Discussion and conclusion}

\subsection{Location of the monitoring points}

In all analyzed systems there is a large inconsistency in the location of monitoring points. In particular, this is evident to WSS3, where there wasn't any monitoring point for heavy metals concentration assessment in water network. The samples analyzed in this 
system were collected from the intake and the water treatment plant. This is due to the fact that this system is a small part of a larger water network in which all network monitoring points are located. For WSS1 the situation looks a little better - about 50\% of monitoring point were located in network, but it still doesn't correspond to the recommendation, which suggest localized monitoring points also in internal installation to take tap water for analyses $[15,24,18]$. The samples for monitoring heavy metals, in this system were taken in 5 places including: 2 schools, hotel, hospital, flat. School, hospital and hotel can be considered as a good choice for localisation of monitoring points.

For WSS1 and WSS3, the amount of samples taken just after the water treatment plant was much higher than in the rest of the system, but assessment of water quality in whole system can't be based just on results from treated water, because it doesn't show the reliable metal concentrations in system.

For WSS2, the situation with monitoring of heavy metals is worst since no heavy metal monitoring points in this system is located, what is incompatible with the regulations.

For WSS2 and WSS3, in the localization of monitoring points, objects recommended in regulations, such as medical facilities and schools have been omitted.

For all analyzed WSS, their broad characteristics are available: building materials, network structure, length, velocity, water divisions, in addition to this WSS1 and WSS2 also have a full hydraulic model of network. Literature analyzes $[13,12]$ show that the data held by the system administrators enable the use of many different monitoring methods, so wondering is, therefore, why they can't completely use them in planning of monitoring process in analysed systems.

\subsection{Number of collected samples}

In accordance with the Polish legal regulations [24], the required annual quantity of water samples tested, for all systems analysed in this articles, should be 16/2 (check monitoring/audit monitoring). With respect to these values only in the WSS1 system, the quantity of water samples doesn't correspond to the provisions of the Regulation. But, if we consider that heavy metals should be included in the audit monitoring, then system WSS2 doesn't meet the requirements of the regulation, too. In the case of WSS3, which is part of the large Water Supply System $\left(15.000 \mathrm{~m}^{3} / \mathrm{d}\right)$, the total number of analysed water samples is theoretically consistent with the regulations [24], but all monitoring points are located outside the WSS3 area, so it can be stated that WSS3 is completely deprived of assessment of water quality (including heavy metals), during its distribution.

Comparing the number of samples collecting in three analysed system with global guidelines, the situation with water quality monitoring seems to be definitely worse. For example USEPA, Russian guidelines, require collecting much more samples for heavy metal monitoring. Both of these methods rely to the number of taken samples, which are calculated based on number of recipients. The amount of water samples required to obtain a reliable water quality image, can also be obtained by statistical tests of power. With regard to these tests, the number of analysed water samples, according to Polish regulations, is several to several hundred times smaller [20].

Table 5. Required quantity of samples according to different guidelines for analysed WSS

\begin{tabular}{|l|c|c|c|c|}
\hline Legal acts/standards/statistical dependence & Poland & USEPA & Russia & Power analysis \\
\hline Required quantity of samples & 2 & 60 & $262^{*}$ & $14 \div 1042 * *$ \\
\hline$*$ ) If the metals are indicated as an additional monitoring range \\
**)One Proportion: Sample Size Calculation, H0: Pi = Pi0 a-0,05; Pi0-0,5; Power Goal-0,9; Pi-0,9 \\
for 14; Pi-0,55 for 1042
\end{tabular}


Table 5 lists the required quantities of samples for monitoring heavy metals in distribution system, for three analysed systems, based on the various available guidelines.

\subsection{Water quality}

In WSS1 and WSS3, the concentrations of heavy metals in treated water, just after water treatment plant, was complied with the provisions of the Polish regulation $[24,33]$.

Changes in the concentration of heavy metals from the intake to internal installations can be analysed only for the WSS1 system, because only in this system, the monitoring of heavy metals is carried out in the way, which allows to perform this kind of the analysis. For the whole WSS1, the metal concentrations in the water were below the limits required in the Regulation [24], but the changes in water quality during transport from the intake to the consumers were noticed (Table 4).

In the water from the network, collected in water mains, there was no increase in the concentration of lead, in relation to the concentrations of this factor indicated in treated water, while double increase in copper concentration in the network was observed, compared to the average concentration indicated in treated water - from $0.0015 \mathrm{mgCu} / \mathrm{L}$ in water treatment plant, to $0.003 \mathrm{mgCu} / \mathrm{L}$ in network. In addition, a further increase in the average concentration of copper, compared to the average concentration in the water network, was noted in internal installations - from $0.003 \mathrm{mgCu} / \mathrm{L}$ to $<0.01 \mathrm{mgCu} / \mathrm{L}$.

There was also an increase in the average concentration of chromium in water from installation installations, with respect to treated water - from $1.6 \mu \mathrm{gCr} / \mathrm{L}$ to $2.7 \mu \mathrm{gCr} / \mathrm{L}$.

In the analysed system, there was noticed also a successive increase in mercury concentrations from $0.06 \mu \mathrm{gHg} / \mathrm{L}$ (for treated water) to $0.076 \mu \mathrm{gHg} / \mathrm{L}$ (for water from network), to $0.2 \mu \mathrm{gHg} / \mathrm{L}$ (for internal installations).

\subsection{Conclusion}

In the investigated systems, water quality monitoring was conducted with high variability over time and with low regularity, in relation to the number of tested samples. Moreover, the location of the monitoring points focused mainly on treated water, which allows us to assume that in the investigated systems there isn't credible monitoring of heavy metals in the water, although monitoring is carried out in accordance with applicable regulations.

Based on the data from WSS1, it can be stated that the analysed water, at each monitoring point, complied with guidelines included in Polish regulations, but it should be presumed, that this is not a complete picture of water quality in this system, because the points in internal installations concerned utilities (schools, hospital, hotel), which are under constant supervision of the sanitary inspection, hence the administrators of these facilities are likely to take special care of their technical condition [33]. Others studies conducted in Poland by Postawa [34] show that, with more detailed monitoring, where the location of the monitoring points was determined by the RDT method, for 1440 samples, there was network zone in which about $8.4 \%$ of water samples had exceeded $10 \mu \mathrm{g} / \mathrm{L}$, and in the other zone there were about $60 \%$ of samples with excess lead concentration.

In future studies, the description of the analysed systems, should be supplemented by a detailed description of the internal installation - age of installations, used materials, the water sampling method, and the way the installations are used by the customers, because all these factors are very important in determining the tap water quality [35, 33].

Symptomatic is, that even small water supply systems, such as the ones analysed in this article, have often very good tools, in the form of hydraulic models, to design reliable water quality monitoring plans in the system, but they don't use them to prepare effective 
monitoring of heavy metals. Probably it will change when the law regulations in this area will changes and administrators of water supply systems will have to build reliable water quality monitoring plans for monitor metals concentrations in water.

It should be emphasized, that according to the Polish regulations, a very serious problem with reliable water quality monitoring, have the small water supply systems where the measurement of heavy metal concentrations is once a year or less often and just in the treated water, not in the network. However, this is a problem that affects small waterworks also in other European countries and in the world.

\section{References}

1. K. Pieper, M. Tang, M.A. Edwards, Environ. Sci. \& Technol., 51(4), 2007-2014 (2017)

2. World Health Organization (WHO), Lead in drinking-water. Background document for development of WHO Guidelines for Drinking-Water Quality. Geneva, World Health Organization (WHO/SDE/WSH/03.04/09;

http://www.who.int/water_sanitation_health/dwq/chemicals/lead.pdf)

3. World Health Organization (WHO), Manual for the public health management of chemical incidents, Geneva, Switzerland (2009), Available online:

http://www.who.int/environmental_health_emergencies/publications/Manual_Chemical_I ncidents/en/,

4. World Health Organization (WHO). Ten Chemicals of Major Public Health Concern, (2010) Available online:

http://www.who.int/ipcs/assessment/public_health/chemicals_phc/en/ (assessed on May 2017)

5. M.A. Edwards , S. Triantafyllidou, D. Best, Environ. Sci.\& Technol., 43 (5), 1618-1623 (2009)

6. N. Zhang, S. Zang, Q. Sun, Ecotoxicology 23, 518-526 (2014)

7. V. Demir, T. Dere, S. Ergin, Y. Cakır, F. Celik, Water Resources 42, 508-516 (2015)

8. N.H.A.Razak, S.M. Praveena, A.Z. Aris, Z. Hashim, J. Epidemiol. Glob. Health 5, 297310 (2015)

9. V. Elumalai, K. Brindha, E. Lakshmanan, Water 9, 234, www.mdpi.com/journal/water, (2017)

10. G. Dorini, P. Jonkergouw, Z. Kapelan, F. di Pierro, S.T. Khu, D. Savic, An efficient algorithm for sensor placement in water distribution systems, 8th Annual Water Distribution Systems Analysis Symposium, Cincinnati, Ohio, USA, August 27-30, (2006)

11. A. Ostfeld, J.G. Uber, E. Salomons, J.W. Berry, W.E. Hart, C.A. Phillips, J.P. Watson, G. Dorini, P. Jonkergouw, Z. Kapelan, F. di Pierro, S.T. Khu, D. Savic, D. Eliades, M. Polycarpou, S.R. Ghimire, B.D. Barkdoll, R. Gueli, J.J. Huang, E.A. McBean, W. James, A. Krause, J. Leskovec, S. Isovitsch, J. Xu, C. Guestrin, J. VanBriesen, M. Small, P. Fischbeck, A. Preis, M. Propato, O. Piller, G.B. Trachtman, Z.Y. Wu, T. Walski, J. Water Res. Plan. Man., 134 (6), 556-568 (2008)

12. S. Rathi, R. Gupta, Procedia Engineering nr 89, 181-188 (2014)

13. E. Hołota, B. Kowalska, JCEEA, 32 (62), 81-98 (2015)

14. E.J. Hoekstra, C.R. Hayes, R. Aertgeerts, A. Becker, M. Jung, A. Postawa, L. Russel, S. Witczak, Guidance on sampling and monitoring for lead in drinking water, European Commission JRC Scientific and Technical Reports EUR 23812 EN, (2009)

15. Lead and Copper Rule Monitoring and Reporting Guidance for Public Water Systems, 
USEPA, (2010)

16. Lead and copper corrosion control in new construction, The report of the research project no. 4164, Water Research Foundation (AWWA RF),US EPA, (2011)

17. USEPA (U.S. Environmental Protection Agency), (2014). USEPA Integrated Risk Information System (IRIS) online database. Available at: http://www.epa.gov/iris (Accessed: Nov. 2015).

18. A. Postawa, S. Witczak, Metale $i$ substancje towarzyszace $w$ wodach przeznaczonych do spożycia w Polsce, Akademia Górniczo-Hutnicza im. Stanisława Staszica w Krakowie, Kraków (2011)

19. B. Clark, S. Masters, M.A. Edwards, Environ. Sci.\& Technol.,48(12), 6836-6843 (2014)

20. C.R. Hayes, N. Croft, E. Phillips, S. Craik, M. Schock, J.of Water Supply: Research and Technology -AQUA, 65(5), 373-383 (2016)

21. S. Chowdhury, M.A.J. Mazumder, O. Al-Attas, T. Husain, Science of the Total Environment, 569-570, 476-488 (2016)

22. S. Masters, J. Parks, A. Atassi, M.A. Edwards, Environ Monit Assess, 188(3):177 (2016)

23. Directive $98 / 83 /$ EC of the November 1998 on the quality of water intended for human consumption-Official Journal of European Communities L 330/32 of 5.1298

24. Regulation of the Polish Minister of Health of 27 November 2015, The Regulation on the quality of water intended for human consumption Dz. U. z 2015 r. poz. 139 i 189

25. Safe Drinking Water Act, Water Infrastructure Improvement for the Nation Act, P.L. 114-322, (2016)

26. Grassroots Rural and Small Community Water Systems Assistance Act, P.L. 114-98, enacted 11 of December, (2015)

27. M. Tiemann, Safe Drinking Water Act (SDWA): A Summary of the Act and Its Major Requirements, Congressional Research Service 7-5700, (1 March 2017)

28. Water Resources Management in Japan, Policy, Institutional and Legal Issues, Environment and Social Development, East Asia and Pacific Region The World Bank, (April 2006)

29. Standard of 2.1.4.1074-01, Drinking water. Hygienic requirements for water quality from centralized water supply systems. Quality control, Russian Federation, (2002)

30. S. Masters, M.A. Edwards, Environ. Eng. Sci. 32(5), 361-369 (2015)

31. Power analysis of statistical tests - http://www.statsoft.pl/textbook/stathome_stat

32. D. Kowalski, B. Kowalska, M. Kwietniewski, Ochrona Środowiska, 35(3), 45-48 (2013)

33. A. Szuster-Janiaczyk, J. Bylka, T. Schiller, M. Skrzypczak, Jakość wody w instalacjach wewnętrznych $\mathrm{w}$ odniesieniu do procesów kształtujących tę jakość, na podstawie wybranego Systemu Zaopatrzenia w Wodę, in Instalacje wodociagowe i kanalizacyjne: projektowanie, wykonanie, eksploatacja, Vol. 3, red. Z. Heidrich, A. Melasińska, J. Chudzicki, Wyd. Seidel-Przywecki sp. z o.o., Warszawa, 2017

34. A. Postawa, J.of Water Supply: Research and Technology-AQUA, 64(1):85 (2015)

35. K. Wątor, A. Mika, A. Postawa, Wpływ materiału instalacji oraz czasu stagnacji wody na stężenia wybranych metali w wodzach przeznaczonych do spożycia in Zaopatrzenie $w$ wodę, jakość i ochrona wód, red. Z. Dymaczewski, J. Jeż-Walkowiak, Poznań, (2016) 